\title{
Discurso Humorístico Cínico na Contemporaneidade: Perspective Histórica e Análise Retórica do Discurso
}

\author{
Discurso Humorístico en la Contemporaneidad: Perspectiva Histórica y Análisis Retórico del \\ Discurso
}

Cynical Humorous Discourse at Contemporaneity: Historical Perspective and a Rhetorical Discourse Analysis

\author{
Mateus Pranzetti Paul Gruda \\ ORCID: http://orcid.org/0000-0001-5251-2874 \\ Universidade Estadual Paulista/Assis, São Paulo/Brasil \\ José Sterza Justo \\ ORCID: http://orcid.org/0000-0002-5472-9900
Universidade Estadual Paulista/Assis, São Paulo/Brasil
}

Declaração de Direito Autoral

A submissão de originais para este periódico implica na transferência, pelos autores, dos direitos de publicação impressa e digital. Os direitos autorais para os artigos publicados são do autor, com direitos do periódico sobre a primeira publicação. Os autores somente poderão utilizar os mesmos resultados em outras publicações indicando claramente este periódico como o meio da publicação original. Em virtude de sermos um periódico de acesso aberto, permite-se o uso gratuito dos artigos em aplicações educacionais e científicas desde que citada a fonte conforme a licença CC-BY da Creative Commons.

\section{Creative Commons Atribuição 4.0 Internacional.}

\section{Resumo}

Nas últimas décadas, o discurso humorístico e seus mecanismos de funcionamento - tais como: ironia, paródia, zombaria - têm sido disseminados por toda e qualquer prática social e discursiva (publicidade, política, moda, educação, dentre tantos outros), se tornando uma importante forma de mediação entre os indivíduos e entre estes e o mundo. O cinismo é outro aspecto relevante no mundo contemporâneo, o qual através de uma racionalidade cínica produz dois processos associados: uma ironização geral das condutas e a defesa de atos imorais por meio de argumentos moralistas. Este ensaio conecta ambos os pontos em um modo específico de funcionamento do discurso humorístico: o humor cínico. Destarte, arrolamos as partes que compõem este texto: (1) comentários preliminares acerca da linguagem enquanto discurso, os aspectos dialéticos do humor e uma breve explicação sobre o esquema de três estágios para a análise retórica do discurso proposto por Simon Weaver; (2) uma razoavelmente ampla revisão acerca das ideias do cinismo propagado na Grécia Antiga (kynismus) e na contemporaneidade (cinismo moderno/contemporâneo); (3) a relação de tais ideias com o humor cínico, sobretudo no que tange aos processos produzidos pela racionalidade cínica; (4) finalmente, um exemplo do humor cínico no Brasil é analisado de acordo com a abordagem metodológica mencionada.

Palavras-chave: Humor; Cinismo; Contemporaneidade; Análise retórica do discurso.

\section{Resumen}

En las últimas décadas, el discurso humorístico y sus mecanismos del funcionamiento - tales como: ironía, parodia, burlas - tienen sido diseminados por toda y cualquier práctica social y discursiva (publicidad, política, moda, educación, entre tantos otros), tornándose una importante forma de mediación entre los individuos y entre esos y el mundo. El cinismo es otro relevante aspecto del 
mundo contemporáneo, o cual a través de una racionalidad cínica produce dos procesos asociados: una ironización general de las conductas y la defensa de actos inmorales por medio de argumentos moralistas. Ese ensayo conecta ambos puntos en uno modo especifico de funcionamiento del discurso humorístico: el humor cínico. Así siendo, exponemos las partes que componen ese texto: (1) comentarios preliminares acerca del lenguaje como discurso, los aspectos dialecticos del humor y una breve explicación sobre el esquema de tres etapas para el análisis retórico del discurso propuesto por Simon Weaver; (2) una razonable amplia revisión acerca de las ideas de cinismo en la Grecia Antigua (kynismus) y en la contemporaneidad (cinismo moderno/contemporáneo); (3) la relación de tales ideas con el humor cínico, especialmente en lo que se refiere a los procesos producidos por la racionalidad cínica; (4) finalmente, un ejemplo del humor cínico en Brasil es analizado conforme la enfoque metodológico mencionado.

Palabras clave: Humor; Cinismo; Contemporaneidad; Análisis retorica del discurso.

\begin{abstract}
On the last decades, humorous discourse and its several mechanisms of operation - such as: irony, parody, mockery - has been spread within distinctive social and discursive practices (advertising, politics, fashion, education, among many others) becoming increasingly important as a form of mediating the relationships among subjects and between subjects and the world. Cynicism is another aspect relevant on the contemporary world, which through a cynical rationality produces two associated process: general ironization of the conducts and defence of immoral acts through moralist arguments. This essay connects both points in a particular way of operating within a general humour: the cynical humour. Hence, outlining the parts of the text, it contains: (1) initial commentaries about the idea of language shaped as discourse; the dialectical aspects of humour; and some explanation regarding the three stages scheme of rhetorical analysis discourse proposed by Simon Weaver; (2) a reasonably huge review about ideas of cynicism propagated in ancient Greece (kynismus) and in the contemporaneity (contemporary cynicism); (3) a relation of those ideas with the cynical humour, mainly related to those processes produced by a cynical rationality; (4) and finally, a Brazilian cynical humour example is analysed according to the methodological approach mentioned.
\end{abstract}

Keywords: Humour; Cynicism; Contemporaneity; Rhetorical discourse analysis.

\section{Introduction}

The importance of language for constituting us as humans is emphasised by authors from different theoretical perspectives which study it (Blikstein, 1995). Here, on this essay, language will be understood as discourse what implies that language is a manifestation and/or materialisation of ideologies, going beyond the grammatical aspects and structures and the function of mere information transmitter or support of thinking (Brandão, 1995; Orlandi, 1999). Therefore, language shaped into discourse format is a socio-historical production and concomitantly a producer of social realities and subjectivities (Parker, 2015; Traverso-Yepez, 1999). Once we comprehend discourse as social production, it is necessary to highlight that it is far away from any neutrality or absence of intentions. Unlike, discourse is a privileged place for demonstration and explicit or implicit materialisation of ideologies with which it is linked (Orlandi, 1999).

Among many different types of discourse, on this essay we will focus on humorous discourse, which has its own particular mechanisms and modes of operation (Attardo, 2014; Palmer, 1994; Possenti, 2010, 2018) and it is widely spread and disseminated into current times (Lockyer \& Pickering, 2005; Gruda, 2015, 2017). Even around the 1980s, Lipovetsky (2005) already analysed the massive presence of humorous discourse contents and forms operating mainly within 
advertising and fashion spheres, because of that this author have concluded: contemporary society is a "humorous society". In last decades, this largely widespread humorous tone embraces every discursive and social practice under a "good humour" label from the commercial advertising of a new line of cars to the pedagogical methods, journalism coverage or political protests organised by social movements.

However, as stated by Ziraldo (Pinto, 1970), a well-known Brazilian cartoonist, humour is dialectical, following the understanding that dialectic is a logic based on the principle of contradiction, wherein opposite polarities exists concomitantly because they deny themselves mutually (Chauí, 1994). This fundamental characteristic is manifested in different periods of history, since humorous discourse received more or less acceptance from diverse social groups and different socio-historical contexts (Critchley, 2002; Geier, 2011; Gruda, 2011, 2017; Lipovetsky, 2005; Minois, 2003). From those authors who have studied and written about humorous discourse, it is possible to assert the multiplicity of social situations in which humour was involved in and was manifested. Moreover, it is possible affirming that humour cannot be labelled as being only "this or that", once humour is dialectical it should be "this and that" at the same time. For examples, humour can be conservative and revolutionary, critical and uncritical, and those features depends on which ideologies humour is linked and on with what kind of discursive, social, and psychological consequences it is producing (Gruda, 2015, 2017). Stressing that humour is dialectical because of such paradoxical contradictions as being universal and particular, social and anti-social and being analysable and resistant to any analysis (Billig, 2005).

Connected with the ideas already exposed, discourse will be interpreted as a rhetorical device (Weaver, 2011), since "humour can develop multiple ideological/discursive effects via its rhetoric." (Weaver, 2013, p. 486). Therefore, humour discourse is not a mere format of discourse, it utters things and collaborates producing ideas, social realities and even subjectivation processes (all of that are the ideological/discursive effects). In other words, humour is engaged indeed and, in spite of being a type of discourse, it conveys serious and implicated thoughts and discursive utterances.

Going further, three stages within rhetorical discourse analysis method described and proposed by Weaver (2011) will be used to analyse one Brazilian cynical humour example. To briefly explain the "parts" of that methodological approach as it follows: on the first stage, discursive content is analysed, thereby linguistic sings and structure that provide humorous effects are the objects of analysis, which are centred in the capacity of inversions of the meanings, creating ambiguous contents and producing incongruities or oppositions. Those aspects and mechanisms lead to interpretation possibilities about humour and at the same time support the propagation of serious and/or ideological ideas through humorous forms.

Afterwards, in the second stage of analysis process, the connotation presented within humorous discourse is focused on, in other words, the several or different ideas that are being propagated by the humorous manifestations become explicit and are not comprehend as only some risible, comic or humorous thing. Therefore, this second stage "[...] explains what exactly, in terms of the meaning of the serious discourse, is to be rhetorically strengthened in the joke." (Weaver, 2011, p. 32). Finally, the discursive and the rhetorical structure of the discourse analysed are correlated, using Weaver's (2011, p. 33) own words: "the third stage of the analysis outlines the structure of the humorous incongruity, identifying the rhetorical device that it is built on.".

To summarise, the first stage is concerned about the form or structure of humour discourse, the second one with the contents conveyed by humour and the last one 
combines both aspects, since the analyses focus on how the structure shapes the form to affirm contents widespread by humorous manifestations. Even though it seems a simplified outline indeed, this is just one possible rhetorical discourse analysis scheme of the three stages, in other words and according to Weaver on a personal communication in 2014 , it does not have to be necessarily understood in that order

Hence, outlining the parts of this essay it contains: (1) a reasonably huge review about ideas of cynicism propagated in ancient Greece and at contemporaneity; (2) a relation of those ideas with cynical humour; (3) and a Brazilian cynical humour sample is analysed following the three stages scheme of rhetorical analysis discourse proposed by Weaver (2011).

\section{A historical perspective: antique cynicism (kynismus) and contemporary cynicism}

Although complex and even dangerous for its potential inaccuracies, Sloterdijk (2012) proposes in his extensive treatise "Critique of cynical reason" a distinction between modern and antique cynicism. Latter is written Kynismus (and its derivate terms as kynismos, kynikoi, kynikai) and it is spelled in Greek on the original language of Sloterdijk's book (German) for strengthen the philosophical differences between those cynicism types. In a few words, this author proposes that was a moment in Western history, approximately around the first century $\mathrm{AD}$, which can be identified into writings of Lucian of Samosata, a satirical orator, wherein the criticism of kynismus was radically disfigured and lost much of its corrosive power, once it have assumed the positions of dominant discourse and hegemonic powers. In other words, at that historical moment cynicism (kynismus) changed sides and started to obey "the logic of lords" (Sloterdijk, 2012, p. 13, translation from Portuguese).

Initially, kynismus was associated with the Greek philosopher Diogenes of Sinope, who has lived around the fourth century BC and was called as "canine philosopher". According to Geier (2011), Diogenes mixed moral seriousness with witty jokes, hated social identifications and despised political power and established values, showing his philosophical positions through radical and practical ways. Diogenes' actions expressed that perspective of kynismus (ironical, hating social values and institutions), such as: he used to live on the polis streets and used to inhabit inside a barrel; he used to satisfy his physiological needs (urination, defecation, masturbation or even having sex) at public spaces; and he regularly used his own hands to eat (he usually eats completely raw food) and drinking water. Though it could be hard to believe that a considered wise man did all those things, but it is recorded in historical documents and is recovered in academical studies (Sloterdijk, 2012; Geier, 2011; Dinnuci, 2010).

With this behaviour Diogenes of Sinope was trying to recover the forgotten animalism that, as maintained by his philosophical point of view, is part of human nature. Besides, through that life perspective he was demonstrating both a clear lack of concern for life's comforts and completely despising for values and social organisation of his socio-historical time. In addition, the canine philosopher had made clear that all those who only care about their careers, money, public acceptance and/or recognition by both small and big powers were simply despicable scoundrels, because according to Diogenes those values have distanced those people from real human nature and made with they have given up of their freedom (Geier, 2011).

There are some legendary episodes involving Diogenes, which show through his actions and word the extreme high level of criticism and hate that he had for power and instituted order. Three of those legends will be briefly unpacked along next lines. It is said that once the Emperor Alexander of Macedonia, also known as Alexander the Great, became intrigued by what he had heard about Diogenes of Sinope - the wise 
philosopher who lived in a barrel - and decided to visit him personally. When he found Diogenes comfortably lay sprawled on the ground, Alexander the Great told the philosopher that he (the emperor) could give anything Diogenes wish for by simply stating what he would want. His answer was reported to be short and direct: "get out of my sun." In other words, the canine philosopher not only asserted his independence and autonomy from the emperor, when he demonstrated that there was nothing that the emperor could give to him, but also decreased and relativised the importance of Alexander the Great, since the heat and light provided by solar rays are preferable to any gift from the emperor.

Other stories recorded said that once the philosopher of Sinope was walking on polis streets carrying a lantern in broad daylight. When he was asked why he was carrying that object in that situation, Diogenes had firmly and rudely replied that he was looking for real Humans. A similar thing has happened when on the public sidewalk the canine philosopher shouted: "Humans come here" and when some passers-by approached him, he hit them with his cane and yelled: "I called for Humans, not trash."

One last consideration regarding this kynismus, initiated by Diogenes of Sinope and subsequently propagated by other philosophers who followed his pack, is about a Minois (2003) reflection. This author asks how much the kynismus really have questioned moral and so-called good manners, since "practicing irony provocatively, they [the Greek Cynics] chased, in fact, a moral purpose, although seeming amoral" (Minois, 2003 , p. 62, translated from Portuguese). From this point of view, through their completely reversing behaviour to what is socially acceptable, appealing to animal nature of humans, Greek cynics wanted to expose and demystify false values that underpin social order, allowing true values to become visible. This criticism of Minois is valid for pointing out the paradox of denouncing false morality and values, while at the same time they were announcing another moral system also allegedly based on true values. However, such criticism loses its power because it overestimates the dichotomy between true and false.

From this polarised division, the caustic power of kynismus actions is relativised since, regardless of defence and pursuit of what is right and judged as essential to humans, Diogenes and those who resembled him were questioning current order in the most radical, funny and outrageous way. The main problem involving what are moral or amoral conducts is that the deviations are common related with aristocratic and religious systems of thinking - and subsequently with what bourgeois ideology defines as immoral -, such as: marital betrayals; thefts and violations of private property; vanity and other infractions of the order that are located mostly in customs. To canine philosopher and his pack, the immorality covered, amongst other dimensions, political life and the inordinate thirst of power and money, which have implied to an exaggerated desire for public recognition; degeneration of the animalistic freedom; and the restrictions and obligations imposed by a specific model of civilisation. Therefore, kynismus criticised and questioned social structure in its base and in essence of its foundations. Going beyond, it did not only focus on superficial manifestations, such as those expressed in everyday custom.

The passage to cynicism - spelled on this way to stress the distinctions between both ideas (kynismus and cynicism) - was a consequence for some intellectualisation of criticism, which meant this was put far away from popular radicalism and animalism propagated earlier by the kyniloi (antique cynics). Luciano of Samosata, an orator who lived in the early period of Roman Empire between the years $120 \mathrm{AD}$ and $180 \mathrm{AD}$, is pointed out by Sloterdijk (2012) as precursor of that disempowerment of kynismus, because, although Luciano has criticised angrily several institutions, cults and customs, he had as his main despising focus the greatest despisers of all, the kynikoi. The tone of Luciano's cynicism was quite similar of contemporary 
cynics and cynicism, wherein criticism switched sides, assuming ideological positions of powerful people and masters. As Sloterdijk affirms: "Luciano speaks here [the German author refers to a paper which Luciano describes, words loaded in satire, the suicide of Peregrinus, leader of a kynike sect] as a cynical ideologue, who names the critics of power as the ambitious crazy." (Sloterdijk, 2012, p. 242, translation from Portuguese). Such logic of cynicism inaugurated by Luciano continues until today, even in terms of this last specific quote referred to, since it is not uncommon people from social movements, who arise in contest to the existing order and resultant social inequalities be labelled as crazy or be mocked by the propagators of such cynical discourses linked with the status quo.

One example of that is Occupy Movement, which promoted the occupation of public squares of major cities around the world during October to December 2011 and was a target of contemporary cynical contempt. This social phenomenon accused the states of refusing to invest in assistance to poor people using liberal justification to avoid guardianship, but readily saving financial system with public money, action that went against states liberal principles. One of the main slogans used by the Occupy Movement ("we are the $99 \%$ against the $1 \%$ ") can be seen connected somehow to kynismus, since it makes explicit the real structure of liberalcapitalistic social order that is based on extreme inequalities - according to OXFAM (2015), $1 \%$ of people (the richest in the world) will have more than $50 \%$ of all global wealth in the next years, besides inequalities are intrinsic to capitalism (Piketty, 2014) -, not on real democracy principles, neither equal rights and conditions.

Several cynical arguments were used to diminish the importance of such event. One of those was that young occupants did not even know what they wanted to, though, as Safatle (2012) affirmed in a public lecture given at Vale do Anhangabaú during the "Ocupa Sampa" (Occupy São Paulo), the greatest achievement of Occupy Movement was raising question in terms of what youngsters did not want, i.e. a social order rooted in inequalities. Another conservative-cynical discourse point against protesters, albeit in more restrained manner, was to calling them "terrorists". This idea was inverted by Žižek (2012) during his speech at Liberty Park in the middle of "Occupy Wall Street" (at New York City). On this occasion he said that terrorists were those ones spread across offices in Wall Street, not within people who were occupying. His principal argument was that financial capital representatives were the ones who caused the severe economic crisis in USA (and consequently at the whole western world), causing mass unemployment and loss of property for thousands of people who had mortgages on their homes.

The analyses of Sloterdijk (2012), Safatle (2008) and Žižek (1994, 2009) reinforce, with particular nuances among them, diagnosis that cynicism is something constituent, inherent and present on the social relationship configurations at contemporary world. However, this cynicism is quite different from kynismus propagated by Diogenes of Sinope, which criticism was imbued with irony and caustic and was straight directed to status quo and instituted rules. Otherwise contemporary cynicism is especially associated with a cynical rationality that produces general ironization of the conducts (Safatle, 2008) and, according to Žižek (1994), defence of immoral acts through moralist arguments.

Hence, this rational and contemporary cynicism disarms the possibility of existent conflicts from processes involving counter values and moral standards, because these are mixed up, making it barely distinguishable (Safatle, 2008). Furthermore, general ironization of conducts is translated into the process of erasing contradictions, “[...] however paradoxical that [this] is, so that the absolute irony [conducts and general] results in the possibility of rationalising and legitimise contradictory positions." (Silva \& Beer, 2011, p. 91, translation from 
Portuguese). This general ironization of the conducts, which does not deny the acceptability of positions and concomitant contradictory values, is something that greatly diminishes the ability of accurate and fierce criticism to status quo. Intense dilution of contradictions by means of indiscriminate irony creates a sui generis situation, neutralising the force of critical discourse to the existing order (as in certain types of humour), and is also dredged up by cynical rationality that is nowadays predominant in control.

Žižek points out (2009) that Marx's phrase "they don't know it, but they are doing it", which summarise Marx's conception of ideology, could be modified on this time of cynical reason dominance to: "they know very well what they are doing, but still, they are doing it", as proposed by Sloterdijk (2012). Before going on, this summary sentence related to contemporary cynicism proposed by Sloterdijk (2012) and discussed by Žižek (1994) will be unpacked a little more. The latter philosopher mentions that this aforementioned phrase can be only taken as a summarisation of cynical rationality if the illusory character of "not knowing" were exactly related to "knowing". Thus, immersed in the perspective of a post-ideological world, not only cynics would have no doubts about the illusion that they follow, as they would stay convinced and would remain devoid of any guilt feelings from their actions. In fact, Žižek (2008, p. 296) tells us in another book that: "[...] the thoroughly cynical power discourse concedes all this in advanced [guilty, traumas], like the analysand of today who calmly accepts the analyst's suggestions about his innermost obscene desires, no longer shocked by anything.". This idea is equal to the situation of the old Psychoanalysis patient, who promptly refuted any connections between a woman that came up in his/her dreams with his/her mother, whilst the current Psychoanalysis patient do not have any problem to confirm a priori that the dreamed woman is his/her mother (Žižek, 2006).

\section{Cynical humour in contemporaneity}

In this part the previous ideas presented will be used to examine what has been called as cynical humour. Following the contemporary cynicism perspective, the principal feature of cynical humour is not being only harmless to established order; it is a real partner of its maintenance, therefore, within this specific type of humour, laughter has a sweet and light intention, which can also weakening any fighting or combative power aspects that humorous discourses have along human history - although, according to Critchley (2002), humour already has been reactionary most part of time for reinforce social consensus. Cynical humour has as one of its main characteristics the ability to promote a frivolous playful mood aligned to the ideal of a light world (Rojas, 1992). In other words, a world devoid of real conflicts or in which these conflicts are eclipsed and obscured by contemporary cynicism.

The targets of cynical humour, of course, are something or someone, but in thesis any lack of compassion, as described by Bergson (2008), is not necessary for joke and/or laughter to occur. Since, the essence of cynical humour is just restating ideas and stereotypes rooted long before into social body, helping not just to strengthen them, but keeping them as well. This attribute can also approach cynical humour to what one of the authors of this article named as uncritical politically incorrect humour (Gruda, 2015, 2017). However, despite of all those points mentioned, cynical humour produces much fewer opposing demonstrations once it is presented as only and supposedly being playful and fun, and thus it is less focused as the object of concern and on questioning social movements and organisations, which frequently occurs in Brazil with the uncritical politically incorrect humour.

Television comedy programs for general public which are proposed as simple entertainment, such as two very popular programs on Brazilian TV "A Praça é Nossa" [in English "The square is ours"] (SBT) and 
"Zorra Total" [in English "Total Mess"] (at Globo Network) are examples of cynical humour manifestations. The sketches presented by those television programs usually show jokes involving characters and situations typical of a humour that seeks only to continue legitimising the ways in which social relations are established. It is possible even to assert that cynical humour would be similar to that humour present in Antique and New Greek Comedies wherein vices and passions were generally mocked for trying moralise society (Minois, 2003). But within cynical humorous discourse, as Žižek stresses (2009), moralisation serves to justify immorality of prejudices, inequalities and oppressions rooted into society. Furthermore, because of the process of general ironization of the conducts (Safatle, 2008), any distinction between serious ideas within those humorous TV programmes are cynically dissimulated, in other words, though aware of reinforcing an oppressive order through humorous utterances, writers and directors of those programmes and the owners of those TV channels as well, keep doing it (Sloterdijk's phrase echoes: "they know very well what they are doing, but still, they are doing it."). After all, this process of eliminating any distinction between things serves to sustain cynically and ideologically the unequal established order.

Consequently, as can be seen in the sketches presented by those aforementioned television programs: adulterers are represented as smart people; corrupt and corrupting citizens are successful; all politicians are corrupt and dishonest; ugly women should take advantage of being sexually harassed; hot women are stupid and gold diggers; black people should not be bothered by being treated as inferior or just for extreme sexual objectification of his/her body and behaviour; indigenous people can be portrayed as solely illiterate and/or exotic; homosexuals men are fragile and homosexuals women are extremely tough; poor people are dirty and stupid; and many others mummified and crystallised conservatives social stereotypes and ideas. However, once those cynical humour television programs are linked with theatrical techniques such as: staging; actors and actress are most of the time wearing costumes and makeup; they (TV programs) can pass for mere entertainment filled with harmless and trivial mockery that subvert any understanding that is, effectively, portraying a prejudiced, exclusionary and sexist dimensions of lived social reality.

\section{Brief analysis of a Brazilian example}

A Brazilian case will be picked to exemplify and analyse cynical humour perspective. There was a sketch on "Zorra Total" (Total Mess in English) broadcasted along 2011-2015 years. Into that there was a female character (Janette) who has been regularly victim of sexual harassment on tube, which is the scenario of the sketch. But, since she is presented as an ugly and undesirable woman, one of her friends (Valeria) always says to her during those abuse situations that she should enjoy the opportunity of sexual contact. The subsequent analysis will follow that rhetorical discourse analysis scheme of three stages proposed by Weaver (2011) already unpacked on "Introduction" part.

In the first stage, it is identified that this sketch uses some theatrical devices, such both characters are using a lot of makeup and clothes that are clearly fancy-dress costumes (Valeria, for example, is a man playing a woman), they speak in ludicrous and fake voice tone, amidst others. Those aspects rhetorically create a non-serious atmosphere and sometimes an exaggerate behaviour of the characters, thereby they should not be perceived as real people - although this is such impossible thing, since every theatrical representation is related to real people and situations -, which could allow the audience to laugh at Janette and Valeria without thinking about what type of discourses are being widespread on this television sketch, furthermore according to main features of cynical humour, it supposed to be just about harmless and fun contents lacked of any serious purposes. 
Subsequently, in the second stage, the analyses focus on the serious and grave situation involving violence against women (an example of it is sexual harassment at public spaces), which by the contemporary cynicism is hidden and transformed in a situation liable to be understood as something unimportant, i.e. and according to this understanding, something just comic, since in a humorous cynical perspective it is something not related to serious purposes - even though contemporary cynics know it is. However, violence against women in Brazil is a fact really worrisome as it is possible to confirm looking at all data available from "Secretaria Nacional de Políticas para as Mulheres" (National Secretariat of Policies for Women) website, for just mentioning one source. Thus, any discourse which naturalises or cynically withdraws seriousness of any questions without promoting some reflections or criticism about that it is only reinforcing this type of action that is not taken seriously.

Finally, in the last stage, it is highlighted cynical humour strategy herein, whereby the exaggerated behaviour of characters are focused on as ludicrous - for example, when someone is sexually harassing Janette, she grimaces and pronounces silly things or sounds, instead of really complaining about the violent action that she is suffering and then this sketch leads the audience to pay attention just to the silly behaviour, when at the same time is laughing about violence and somehow confirming that this is not a problem at all, perhaps, without verbalising, some members of audience could be thinking: "for a ugly woman this could be a real opportunity to be sexually desired". A serious matter is transformed cynically and through cynical humour as something non-serious and concomitantly it is reinforced as something natural, or worst, as something acceptable, which in the end of the day just confirms the chauvinist and misogyny established and dominant order that is lived routinely in Brazil.

\section{Final considerations}

When it is assumed that humorous discourse and its mechanisms and code of function are becoming increasingly important as a form of mediating the relationships among subjects and between subjects and the world (Critchley, 2002; Justo, 2006; Lipovetsky, 2005), it is necessary to seek and analyse its modes of operation and its ideological ties, trying to understand which social realities and subjectivities are being produced and what are the worldviews that are being presented and/or questioned through humorous manifestations. It is also relevant to understand humour as a fundamentally dialectical and discursive manifestation that is produced and interpreted by different sociohistorical and cultural contexts.

This essay focused especially on cynical humour, thus historical aspects of cynicism were recovered to delimit some differences between antique cynicism (kynismus) and contemporary cynicism. Latter one is status quo partner for despising who criticise power, the mighty ones, and the social order, besides it produces an idea that there are no boundaries anymore through its cynical rationality, i.e. even criticisms to the established order and the institutions and power ones are not possible. Differently from kynismus that was strongly critic to the customs, institutions and, power figures. Also comprehending that humour mechanisms are involved with these cynical practices (irony; sarcasm; reverse meanings, among others).

Afterwards the principal contemporary cynical features (general ironization of the conducts; and defending immoral acts through moralist arguments) were depicted in a Brazilian humorous example picked from a television programme well-known in that country. Finally, the analyses were made using Weaver's (2011) three stages scheme of rhetorical analysis discourse. 


\section{Referências}

Attardo, S. (org.). (2014). Encyclopedia of humor studies. Los Angeles: SAGE.

Bergson, H. (2008). Laughter: An essay on the meaning of comic. Rockville: Arc Manor.

Billig, M. (2005). Laughter and Ridicule: Towards a Social Critique of Humour. London: SAGE Publications.

Blikstein, I. (1995). Kaspar Hauser ou A fabricação da realidade. São Paulo: Cultrix.

Brandão, H. (1995). Introdução à Análise do Discurso. Campinas: UNICAMP Press.

Chauí, M. S. (1994). O que é ideologia?. São Paulo: Brasiliense.

Critchley, S. (2002). On humour. London: Routledge.

Dinnuci, A. (2010). Diógenes, o cão: imagens, ditos célebres, comentários, epigramas. Prometeus - Filosofia em Revista, 5(3), 8599. Recuperado de https://seer.ufs.br/index.php/prometeus/arti cle/view/752

Geier, M. (2011). Do que riem as pessoas inteligentes?: Uma pequena filosofia do humor. Rio de Janeiro: Record.

Gruda, M. (2011). O discurso do humor politicamente incorreto e do escracho em South Park (Dissertação de Mestrado). Faculdade de Ciências e Letras, Unesp, Assis.

Gruda, M. (2015). Some critical reflections about politically incorrect humour at contemporaneity. Psychology Research, 5(8), 484-495. doi: 10.17265/21595542/2015.08.005

Gruda, M. (2017). O discurso do humor politicamente incorreto no mundo contemporâneo. São Paulo: Cultura acadêmica.

Justo, J. (2006). Humor, educação e pósmodernidade. In V. Arantes (org.), Humor e alegria na educação (pp. 103-112). São Paulo: Summus

Lipovetsky, G. (2005). A era do vazio. Barueri: Manole.

Lockyer, S., \& Pickering, M. (orgs.). (2005). Beyond a joke: the limits of humour. New York: Palgrave Macmillian.
Minois, G. (2003). História do riso e do escárnio. São Paulo: UNESP.

Orlandi, E. (1999). Análise de discurso Princípios \& Procedimentos. Campinas: Pontes.

OXFAM. (2015). Wealth: having it all and wanting more. Oxfam Issue Briefing [Online]. Recuperado de https://www.oxfam.org/sites/www.oxfam.o rg/files/file_attachments/ib-wealth-havingall-wanting-more-190115-en.pdf

Palmer, J. (1994). Taking humour seriously. London: Routledge.

Parker, I. (2015). Psychology after discourse analysis: concepts, methods, critique. London: Routledge.

Piketty, T. (2014). Capital in the Twenty-First Century. Cambridge, MA: Harvard Universtity Press.

Pinto, Z. (1970). Ninguém entende de humor. Revista Vozes de Cultura, 3(64), 21-37.

Possenti, S. (2010). Humor, língua e discurso. São Paulo: Contexto.

Possenti, S. (2018). Cinco ensaios sobre humor e análise do discurso. São Paulo: Parábola.

Rojas, E. (1992). El hombre light. Buenos Aires: Planeta.

Safatle, V. (2008). Cinismo e falência da crítica. São Paulo: Boitempo.

Safatle, V. (2012). Amar uma ideia. In D. Harvey et al., Occupy: movimentos de protesto que tomaram as ruas (pp. 45-55), São Paulo: Boitempo.

Secretaria nacional de políticas para mulheres. (2018). Recuperado de http://www.spm.gov.br/

Silva, P., \& Beer, P. (2011). Sobre o cinismo em um tempo de identificações irônicas. Trivium - Estudos Interdisciplinares, 1(3), 84-98. Recuperado de http://pepsic.bvsalud.org/scielo.php?script= sci_arttext\&pid=S2176$48912011000100009 \& \operatorname{lng}=\mathrm{pt} \& \mathrm{t} \operatorname{lng}=\mathrm{pt}$

Sloterdijk, P. (2012). Crítica da razão cínica. São Paulo: Estação Liberdade.

Traverso-Yepez, M. (1999). Os discursos e a dimensão simbólica: uma forma de 
abordagem à Psicologia Social. Estudos de Psicologia (Natal), 4(1), 39-59. doi: 10.1590/S1413-294X1999000100004

Weaver, S. (2011). The Rhetoric of Racist Humour: US, UK and Global Race Joking. Ashgate Publishing.

Weaver, S. (2013). A rhetorical discourse analysis of online anti-Muslim and antiSemitic jokes. Ethnic and Racial Studies, 36(3), 483-499. doi: 10.1080/01419870.2013.734386

Žižek, S. (1994). Mapping ideology. London: Verso Books.
Žižek, S. (2006). Freud Lives!. London Review of Books, 28(10), 32. Recuperado de https://www.lrb.co.uk/v28/n10/slavojzizek/freud-lives

Žižek, S. (2008). In defense of lost causes. London: Verso Books.

Žižek, S. (2009). The sublime object of ideology. London: Verso Books.

Žižek, S. (2012). O violento silêncio de um novo começo. In D. Harvey et al., Occupy: movimentos de protesto que tomaram as ruas (pp. 15-25). São Paulo: Boitempo

\section{Dados sobre os autores:}

- Mateus Pranzetti Paul Gruda: Doutor em Psicologia Social pela UNESP-Assis (bolsa de doutorado FAPESP), Pesquisador Estagiário no Centre for Comedy Studies Research da Brunel University London (bolsa de doutorado sanduíche da CAPES), Pós-doutorando (bolsa capes) pela UNESP-Assis.

- José Sterza Justo: Doutor em Psicologia pela PUC-SP, Livre-Docente pela UNESP-Assis, professor aposentado do Departamento de Psicologia Social e Educacional da UNESP-Assis. 